IJAMSR 3 (9) www.ijamsr.com CrossRef: https://doi.org/10.31426/ijamsr.2020.3.9.3712

International Journal of

\title{
FRIEDRICH AUGUST FROEBEL KINDERGARTEN SYSTEM AND HIS MAIN CONTRIBUTION TO EDUCATION
}

\author{
Dr. Rayees Ahmad Dar \\ Faculty of Education, University of Kashmir, Kashmir, India. \\ Email: rayees78601@gmail.com
}

Keywords:

Kindergarten, contribution, Gifts, Play way method

\begin{abstract}
A B S T R A C T
Among the great educators Froebel appears a man afflicted with new ideas which he put effectively into practice. He brought about a revolution in child education. He stressed that childhood is not merely preparation for adulthood but a value in itself. The educator ought to lead the child through such situations which help to relate his experiences organically. Only then child can realize his own personal unity and unity in the diversity of life. Froebel's educational philosophy in the field of education give insight to the teachers into the varied educational problems related to aims, methods, content, administrative pattern etc which not only enables them to solve at the intellectual and philosophical level but also at the factual and emotional level. It serves a guiding force for teachers for perusing their profession as devoted and enthusiastic work. Froebel had a living perception of universal and ideal truth. He had unbounded enthusiasm for the education and happiness of human race. All the best tendencies of modern thought in education culminate in what was said and done by Froebel. . Though the philosophers have sometimes emphasized on this or that method exclusively, yet all the methods have been found to be useful in philosophical thinking. A researcher in the area of educational philosophy aims at analysis of the meaning and nature of different kinds of educational practices. The researcher identifies appropriate norms and standards. This paper studied the relevance of kindergarten of Froebel.
\end{abstract}

Citation: Rayees Ahmad Dar (2020). Friedrich August Froebel Kindergarten System And His Main Contribution To Education. International Journal of Advanced Multidisciplinary Scientific Research (IJAMSR) ISSN:2581-4281, 3 (9), September 2020, Pp 13 -25 
IJAMSR 3 (9) www.ijamsr.com CrossRef: https://doi.org/10.31426/ijamsr.2020.3.9.3712

\section{Introduction}

The kind of education which the nineteenth century calls the new education is based on the works of many thinkers and Frobel is one among them. He for the first time applied the idea of unity and spontaneous growth to education. He believed that Divine essence of man should be unfolded, brought out lifted into consciousness. Education should lead and guide man to clearness concerning him and in himself, to peace with nature, and to unity with God; hence, it should lead him to knowledge of himself and of mankind, and to the pure and holly life to which such knowledge leads. Although Froebel himself said that centuries would pass before his views of the human creature as manifested in the child and of the educational treatment it required would be universally received. Yet it can be seen that Froebelian kindergarten soon caught the eye of the educational world. Since his kindergarten school has sprung up rapidly in all the progressive countries of the world. Many tendencies in the curricula and methods of the school can be traced back to him. To him the child was inherently good, recognizing the importance of the native capabilities of children he advocated a sympathetic regard for these both by parents and teachers. It was he, who created a new respect for the individuality of the child. Froebel realized the value of discovering and developing the individuality by means of initiative, execution and cooperation in educational process. Since then these have become the by words in educational theory and practice. He has inspired the various arts and crafts like clay modeling etc in the modern education. His emphasis upon activity and social participation and a school without books and set tasks, was a unique contribution to educational practice. $\mathrm{He}$ impressed upon the educational world that rigid discipline and the traditional formality of the school atmosphere must be given up so as to develop the dynamic and active qualities of the child's nature. His emphasis upon the manipulation of the objects and freedom to express oneself produced a greater attention to activity and sense realism in place of the constant and regimented reading of books. $\mathrm{He}$ wanted the education to fit the individual for full life within the group and aimed to open up pupils whole wide range of human knowledge and experience. His conception forms the chief concern of education today. His view that education is a growth and a growth from within of the native powers of the child held a great 
IJAMSR 3 (9) www.ijamsr.com CrossRef: https://doi.org/10.31426/ijamsr.2020.3.9.3712

influence on the later thought of teaching theory and practice. His doctrine that knowledge is not the end of education but the means towards the end minimized the value of verbalism. His recognition of the educational value of play, self-activity, creative work, social participation and learning by doing are psychologically, socially and practically sound. Froebel was a person who never ceased to systematize, symbolize, idealize identities and analyze among all facts and phenomena of the universe. He made life more simple, clear and more recognizable. Among the great educators Froebel appears a man afflicted with new' ideas which he put effectively into practice. He brought about a revolution in child education. He stressed that childhood is not merely preparation for adulthood but a value in itself. The educator ought to lead the child through such situations which help to relate his experiences organically. Only then child can realize his own personal unity and unity in the diversity of life. Froebel's educational philosophy in the field of education give insight to the teachers into the varied educational problems related to aims, methods, content, administrative pattern etc which not only enables them to solve at the intellectual and philosophical level but also at the factual and emotional level. It serves a guiding force for teachers for perusing their profession as devoted and enthusiastic work. Froebel had a living perception of universal and ideal truth. He had unbounded enthusiasm for the education and happiness of human race. All the best tendencies of modern thought in education culminate in what was said and done by Froebel.

\section{Statement of The Problem}

The problem under investigation reads as under: "Friedrich August Froebel kindergarten system and his main contribution to the education".

\section{Objectives of The Study}

The following objectives were formulated for the present study:

a) To study the kindergarten system of Friedrich Froebel.

b) To study the relevance of his educational philosophy to the contemporary society. 
IJAMSR 3 (9) www.ijamsr.com CrossRef: https://doi.org/10.31426/ijamsr.2020.3.9.3712

\section{Methodology}

Philosophical method, according to Passmore (1967) is not exclusively employed by philosophers only. Every man utilizes philosophical method in his thinking on philosophical problems. However, the philosophical method is mainly utilized by the philosophers. The philosophical method is not absolutely different from scientific method because every method has its own procedure to investigate truth. There seems to be as many philosophical methods as there are different philosophies. Philosophical method is multi sided. Though the philosophers have sometimes emphasized on this or that method exclusively, yet all the methods have been found to be useful in philosophical thinking. A researcher in the area of educational philosophy aims at analysis of the meaning and nature of different kinds of educational practices. The researcher identifies appropriate norms and standards

\section{Kindergarten}

Froebel started a school at Blankenberg (Germany) for small infants and called it Kindergarten means a $a^{e e}$ garden of children ${ }^{\text {ee }}$ and was designed to be a place where children were ,allowed to blossom ${ }^{\text {ee }}$. Froebel regarded this school as a garden and the teacher as a gardener who carefully tends the little human plants under his care and helps them grow to beauty and perfection. There is an atmosphere of self activity, play and joy in the school. Children are given freedom in activity while Froebel saw this as a gentle type of education, it was really quite structured. Children were instructed in their play. For example, children were told that the configuration of blocks was a stable and that they should play with the horse figurines near the stable. Rather than allowing the child to determine what the configuration of blocks represented to them, or allowing the child to manipulate the blocks himself, the child was gently pushed in a certain direction. Basics of kindergarten system Kindergarten system is based upon the following principles:

\section{i) Self-Activity:}

Self-activity is spontaneous in which the child carries out his own impulses and motives. Such activity directs the growth of the child along the lines of racial development. So it merges the individual spirit with the spirit of humanity. Self-activity, in fact, is self-realization through which the child comes to know of his own nature as well as the life around him. Thus, 
IJAMSR 3 (9) www.ijamsr.com CrossRef: https://doi.org/10.31426/ijamsr.2020.3.9.3712

self-activity not only fills the gap between knowledge and action but also gives joy, freedom, contentment and peace of mind. Selfactivity is promoted through song, movements and construction. According to Froebel, real development of the child is possible only through self-activities. It gives joy, freedom, contentment and peace. It enables the child to reveal his personality and attain selfrealization. Froebel believed that child was not to indulge in an activity that was suggested by parents or teachers. He stresses that the child should be given full freedom to carry out his own impulses and decisions. He regarded selfactivity as a process by which the individual realizes his own nature and builds up his own world and then unites and harmonizes the two. Froebel believed education is a process of individual growth, this growth is directed by inner forces in the child, and this growth of child differs from that of a plant, as the child has perception and reason. Froebel said that the divine spirit reveals itself in the activities of the child, if these activities are spontaneous. This free self - activity directs growth along the path of racial development. It is this self - activity which merges the child's individuality with the spirit of humanity. Only the teacher should provide appropriate experiences. Self - activity helped the instruction to go on steadily, continuously, gradually and inwardly, without any tricks of education like, from the simple to the complex and from the concrete to the abstract. Self-activity, therefore, arises out of one's own interests and is sustained by one's own power. It alone can produce the evolution of mind and can secure the aim of education. Since self - activity arises out of inner urges, it can be called free. Since these free activities take place according to the laws of nature, it is possible to formulate them in such a way that they become guide to educational work. It is, therefore, essential that all process of instruction must originate with the interests of the child. Self - activity manifests in the child desire to enter into the life around it, the desire to help, to find out, to discover, and to participate in common activities.

\section{ii) Learning by Playing:}

Play is the purest most spiritual activity of man at this stage and at the same time, typical of human life as a whole of the inner hidden natural life in man all things. It gives, therefore joy, contentment, inner and outer rest, peace with the world. It holds the source of all that is good. Children love to play and it is their natural instinct. The play-way method was 


\section{International Journal of \\ Advanced Multidisciplinary Scientific Research (IJAMSR) ISSN:2581-4281}

conceived by Froebel, who is also the father of the Kindergarten method. 'Play' according to Froebel is the work of the children. It is 'the purest, the most spiritual, and product of man at this stage.

\section{iii) Freedom in Education:}

Froebel gives prominent place to the concept of freedom in the education of child. Froebel was against the traditional aims, ideals, curriculum and methods of teaching. Froebel puts the child at the central position of educational process. Full freedom is given for the expression of activities and educational development of a child. $\mathrm{He}$ is not interfered from outside at all. For Froebel in good education, in genuine instruction, in true training, necessity should call forth freedom; law, self determination; external compulsion, inner free will; external hate, inner love. Where hatred brings forth hatred; law, dishonesty and crime; compulsion slavery; necessity, servitude; where oppression destroys and debases; where severity and harshness give rise to stubbornness and deceit. All education is abortive. In order to avoid the latter and to secure the former, all prescription should be adapted to the pupil's nature and needs, and secure his cooperation. This is the case when all education in instruction and training, in spite of its necessarily categorical character, bears in all details and ramifications the irresistible impress that the one who makes the demand is himself strictly unavoidably subject to eternally ruling law, to an unavoidable eternal necessity and that therefore, all despotism is banished.;

\section{iv) Social Participation:}

Froebel believes that man is essentially a social animal by nature. It is the primary instinct of man to live in the company of other persons. Froebel emphasized the social aspect of education and advocated that home, school, church, vocation and the state, should all provide opportunities to children for social participation. By participating in co-operative activities, the child not only receives physical training but also intellectual, social and moral education

From the very beginning, children should be trained to lead a group life and to live well in the society for developing different aspects of personality. Froebel asserted that the real education can take place in the company of others because the life of the individual is an integral part of the society. He believed that all 
IJAMSR 3 (9) www.ijamsr.com CrossRef: https://doi.org/10.31426/ijamsr.2020.3.9.3712

social institutions like the home, the school, the church and the state etc. are the agencies of development of the individual wherein he is to realize the unity in diversity. Froebel believes that man is essentially a social animal by nature. It is the primary instinct of man to live in the company of other persons. Froebel emphasized the social aspect of education and advocated that home, school, church, vocation and the state, should all provide opportunities to children for social participation. By participating in co-operative activities, the child not only receives physical training but also intellectual, social and moral education.

\section{Techniques of Teaching in Kindergarten:}

In the Kindergarten system songs, gestures and construction are important avenues for self expression and essential development of the personality of the child. Along with this Mother's play and songs, gifts and occupations have also been laid down.

\section{i) Teaching Through Songs}

Froebel saw an organic relationship between songs, gestures and construction. He regarded these as three coordinate forms of expressions in the child. What is to be learnt by the pupils is expressed in a song, and then it is dramatized or expressed in gestures or movement and lastly illustrated through some constructive work such as paper or clay. Thus a balanced development of the mind, the speech organs and the hand is aimed at. These three activities provide exercise to the senses, limbs and muscles of the child.

\section{ii) Teaching Through Gifts and Occupations}

Gifts and occupations of Froebel are the most conspicuous contribution to the methodology of nursery education. Gifts are simple educational toys which are presented to the child in a definite order, without charging their forms. The child is given the freedom to handle them in any way, he likes.-while gifts signify the material, occupations represent activities which are suggested by that material and which can be continued with its help. Gifts are in the shape of wooden balls of different colors, wooden spheres, cubes and cylinders of different types and sizes. Additional gifts are in the form of wooden squares, triangles, tables, sticks and rings. Occupations include activities like construction with paper, clay, wood and materials. It may, however, be noted that gifts and occupations have a definite purpose behind them. They train the senses of sight and touch. They give the idea of size, form and surface. 
They also develop the number sense and artistic consciousness. In this way they facilitate further instruction in Algebra, Geometry, Trigonometry and Drawing. And as Rusk says, "By his methodological arrangement of the gifts and occupations, Froebel nevertheless founded a new type of educational institution and although his system too readily lent itself to formalism by later generations of teachers who had not the spirit of the natter, it ameliorated the lot of countless children." For the complete education and training of the child, Froebel devised a series of gifts. The gifts comprise carefully graduated series of materials which possess all the novelty of playthings, and form the basis of his educational method. They are to train the sense of sight and touch, to give the child an idea of size and surface, and to present him a correct idea of number. The activities suggested by these gifts are called occupations. The gifts are given to the child in a certain order. The gradation and order elements of gifts are determined by the principle of development. The gifts are twenty in number although only the first seven are now usually called by this name.
GIFT I: It consists of six colored woolen balls, three in primary colors, red yellow and blue and three secondary colors, orange, green and purple. The occupation consists in rolling them about in play. Thus they develop in the children the idea of colour and materials and form motion, direction and muscular sensibility.

GIFT II: It consists of a sphere, cube and cylinder made of hardwood. In playing with these gifts. The child notices the difference between the stability of the cube and the mobility of the sphere. He observes that the cylinder is both stable and movable, and that it harmonizes both the qualities in one.

GIFT III: It is a large cube divided into eight smaller equal cubes. From these the child can build up a number of useful artistic forms such as benches, steps, doors, bridges etc and for this reason the third gift is often called the first building box. The child can also gain elementary ideas of addition and subtraction through these cubes.

GIFT IV: It consists of the large cubes divided into eight oblong prisms in each of which the length is twice the breadth and the breadth is twice the thickness. This helps the child to 
IJAMSR 3 (9) www.ijamsr.com CrossRef: https://doi.org/10.31426/ijamsr.2020.3.9.3712

construct different kinds of buildings and patterns when combined with the third gift.

GIFT V: It is very much like the third gift. It consists of a large cube divided into twenty seven small cubes, three of which are again divided diagonally into halves and three into quarters. The child can construct many beautiful forms and patterns by combining the third, fourth, and fifth gifts. Form and number can very well be taught by the use of this gift.

GIFT VI: It is again similar to gift four. In it there is a large cube divided into eighteen whole and nine small oblong blocks. Still further designs in forms and construction may be made by the child. It is also useful in teaching numbers.

GIFT VII: It is also a set of square and triangular tables made of fine wood in two colors. It provides materials for several exercises in geometrical forms and mosaic work. other gifts consists of materials such as stick laying, perforating, paper cutting, threading of beads, mat making, embroidery, basket making, wire work, drawing and modeling.

\section{Relevance in the Contemporary Society}

His emphasis upon the manipulation of objects and freedom to explore and express oneself produced a greater attention to activity and sense realism in place of the constant and regimented reading of books. The child, he said, is "replete with all the active tendencies of human nature". The notion of group activity as natural means of expression led to the realization of the importance of good social relationship as a desirable result of school and community life. Froebel the full social significance of education is fuzzy grasped. $\mathrm{He}$ wanted the education to fit the individual for full life within the group and aimed to open up to pupils the whole wide range of human knowledge and experience. It is the working out this conception that forms the chief concern of education today. No phase of school work has so closely, ,approximated the idea of society in microcosm ${ }^{e e}$ as has the Kindergarten. Froebel's view that education is a growth and a growth from within of the native powers of child held a great influence on the later thought of teaching theory and practice. His doctrine that knowledge is not the end of education but the means towards the end minimized the value of verbalism. His recognition of the 
IJAMSR 3 (9) www.ijamsr.com CrossRef: https://doi.org/10.31426/ijamsr.2020.3.9.3712

educational value of play, self-activity, creative work, social participation and learning by doing are psychologically, socially and practically sound. They have been embodied in educational practices from the infant schools to Universities. Froebel was a great exponent of the fundamental use of play and education. But he believed in guided and progressive activities. It was on account of purposeful activity that he identified play and work as one. Froebel was the first to take the formative and creative instincts of children into account for education. His doctrine of play has had the greatest influence upon educational practice. It formed the centre of new education. Its spirit runs into project method and in the whole range of experimental and creative activities of the modern progressive schools. Kindergarten has been declared to be, "by far the most original, attractive and philosophical form of infant development, the world has yet seen," and it has spread in all progressive lands. Froebel completed the system of Rousseau by providing the richer and more stimulating environment which was denied to Emile." Froebel adopted Pestalozzi's objective methods of teaching geography, natural history, arithmetic, drawing, writing, reading and constructive geometry. Like Rousseau he believed, that nature is infallible and advocated the physical training and excursion as means of study. As well said by Froebel that education is a natural process, that child is an organic whole itself and is an organic part of the society and that the whole universe is an organism of which all lesser organisms are members. His faith in man's relationship with nature, his advanced scientific thought, his belief that universe has emerged by a process of evolution with which the education should be in harmony were his greatest contributions. He was the first educational evolutionist. Education to him was the process by which the race and the individual evolve to higher and higher levels. Froebel's permanent contribution to education may be summarized in the following way: The natural course of the evolution of the child's activities should be the main guide in education of the child. Inner-self activity directs the development and early education should be organized around play. Physical, mental and moral powers should be developed and harmonized through constructive activity. Spontaneity and social control may be harmonized through creative activity. The curriculum should be based on the activities and interests of children. The education of women should be regarded as essential for the 
IJAMSR 3 (9) www.ijamsr.com CrossRef: https://doi.org/10.31426/ijamsr.2020.3.9.3712

development of human race. Education can ensure the future evolution of mankind. Froebel exercised great influence in making people realize that the early year of the child are very important for education and that correct, proper and special type of education should be imparted at this stage. Froebel emphasis is on child centered curriculum. Child will learn many special qualities such as love, sympathy, fellow feeling, cooperation etc through group activities. Froebel regards man's life as a continuous process of development or of evolution from within. "It is highly importance," he affirms, "that man's development should process continuously from one point, and that his continuous progress be seen and ever guarded. Notwithstanding Froebel's insistence on the continuity of development he does not hesitate to distinguish well-marked stages and to set these in opposition one to the other. This, the period of boyhood is predominantly that of life for the mere sake of living, for making the internal external; the period of boyhood is predominantly the period of learning, for making the external internal. The former is the period of play, the latter of work, "what formerly the child did only for the sake of the activity, the boy now does for the sake of the result or product of his a activity," "while during the period of childhood the aim of play consisted simply in activity as such, its aim lies now (in boyhood) in a definite conscious purpose." "If activity brought joy to the child, work now gives delight to the boy." Play is the characteristic activity of childhood says Froebel's; it is the highest phase of childdevelopment. Play is the purest, most spiritual activity of man at this stage, and, at the same time, typical of human life as a whole - of the inner hidden natural life in man and all things. It gives, therefore, joy, freedom, contentment, inner and outer rest, peace with the worked. It holds the source of all that is good. Froebel's demand for the inclusion of manual work in the school curriculum is based on his idealistic conception of work. Manual work is a necessary condition of the realization of the pupil's personality; through it he comes to know himself. "Every child, boy, and youth whatever his condition or position in life, should devote daily at least one or two hours to same serious activity in the production of some definite external piece of work. Children, mankind, indeed - are at present too much concerned with aimless and purposeless pursuits, and too little with work. Children and parents consider the activity of actual work so 
IJAMSR 3 (9) www.ijamsr.com CrossRef: https://doi.org/10.31426/ijamsr.2020.3.9.3712

much to their future conditions of life that educational institution should make it one of their most constant endeavors to dispel this delusion.

\section{Conclusion}

The domestic and scholastic education of our time lead children to idleness and laziness; a vast amount of human power thereby remains undeveloped and is lost. In conclusion it may be seen that no educational theory has been more followed in actual practice than that of Froebel. Froebel's educational principles have been accepted as basic for education at all levels- from primary stage to university. Modern education will ever remain indebted to Froebel. All the best tendencies in modern education can be traced back to what Froebel stood for century ago. Froebel was first who drew the attention of the society towards education of every young child. The formalism of the kindergarten system may be subject to much criticism. But its methodical arrangement of plays and occupations invited the active interest of many who lack the spirit of the master to give ,playe a place into schools. The most lasting contribution of Froebel lay in his development of the kindergarten .This idea found a ready response in the United States. Today, we realize the importance of the Kindergarten as a socializing force, and we have made it a primary foundation of our educational system. Froebel was right in his belief that education has a transcendental function, it points not only to man's social nature but also to his metaphysical ideals. Education thus becomes an expression of man's ultimate hopes.

\section{References}

1) Armstrong, M. (2006). A Handbook of Human resource Management Practice, Tenth Edition, Koran Page Publishing, London, , p. 264

2) Christen, M., Ayer, G. and Sober man, D. (2006). Job Satisfaction, Job Performance, and Effort: A Reexamination Using Agency Theory, Journal of Marketing, January, Vol. 70, pp. 137-15

3) Davis, K. and Nostrum, J.W. (1985). Human Behavior at work: Organizational Behavior, 7 editions, McGraw Hill, New York, p.109

4) Diuguid, Darraya.R( 2009). Studied Student Teachers Awareness, Preparedness and Attitudes of Issues Related to high Poverty Schools. . Journal of Experimental Education June 1955.

5) Herzberg, H. F. (1976). Motivation-Hygiene Profiles, p. 20 George, J.M. and Jones, G.R. (2008). Understanding and Managing Organizational behavior, Fifth Edition, Pearson/Prentice Hall, New Yersey, p. 78

6) Hop pock, R. (1935). Job Satisfaction, Harper and Brothers, New York, p. 47

7) Kaminski, B.S. (2007). Encyclopedia of Business and Finance, Second edition, Thompson Gale, Detroit, p. 446 
IJAMSR 3 (9) www.ijamsr.com CrossRef: https://doi.org/10.31426/ijamsr.2020.3.9.3712

8) Lawler, E.E and Porter, L.W. (1967). The Effect of Performance on Job Satisfaction, Industrial Relations, pp. 20-28

9) Locke, E.A. and Latham, G.P. (1990). A theory of goal setting and task performance, Prentice Hall, p.4 Lufthansa, F. (1998). Organizational Behavior, 8 Editions, McGraw-Hill/Irwin, Boston, p. 147

10) Mullins, J.L. (2005). Management and organizational behavior, Seventh Edition, Pearson Education Limited, Essex, p. 700

11) Mrunalini, T. \& Sankaraih. (2010). Study on Attitudes and Reflections of Prospective Teachers on Environmental Concerns. Social psychology of Education, 6,61-90.

12) Pandey, R and Tripathy,(2006). Attitude towards teaching, Harper and Brothers, New York, p. 47

13) Rue, L.W. and Byers, L. (2003). Management, Skills and Application, 10 ed., McGraw-Hill/Irwin, New York, p. 259

14) Reno and Nanda (1999) ). A theory of goal setting and task performance, Prentice Hall, p.4

15) Specter, P.E. (1997). Job satisfaction: Application, assessment, causes and consequences, Thousand Oaks, Corsage Publications, Inc Stat, D. (2004). The Rutledge Dictionary of Business Management, Third edition, Rutledge Publishing, Detroit, p. 78
16) Sweeney, P.D. (2005). Organizational Behavior, Solutions for Management, McGraw-Hill/Irwin, New York. 57

17) Sunitha and Badola, (2010). Study on studied, IGNOU (B.ED.)Teacher Trainees Attitude towards Awareness of the Fundamental Rights of Secondary school Students rights of secondary school students. . Journal of Higher Education Policy Management, vol.21, no.2, pp. 203-214.

18) Selvaraj Gnanaguru, A \& Suresh Kumar, M, in (2008). Study on under Achievement of B.Ed Students in Relation to their Home Environment and Attitude towards Teaching. . Journal of Higher Education Policy Management, vol.21, no.2,pp. 203214.

19) UNESCO, (1998). World Declaration on Education for All. Adapted by the World conference on Education for all meeting basic Learning Needs. Jomtin, Published by UNESCO. 